\title{
Toxocariasis in urban environment of western Slovakia
}

\author{
F. ONDRISKA ${ }^{1}$, K. MAČUHOVÁ ${ }^{2}$, J. MELICHEROVÁ ${ }^{2}$, K. REITEROVÁ ${ }^{3}$, D. VALENTOVÁ ${ }^{4}$, V. \\ BELADIČOVÁ $^{4}$, J. HALGOŠ ${ }^{2}$
}

\begin{abstract}
${ }^{1}$ HPL (Ltd) Medical Laboratories, Istrijská 20, 84107 Bratislava, Slovak Republic, E-mail: ondriska@hpl.sk; ${ }^{2}$ Department of Ecology, Faculty of Natural Sciences Comenius university, Mlynská dolina 842 15, Bratislava, Slovak Republic, E-mail: katarina.macuhova@gmail.com, halgos@fns.uniba.sk; ${ }^{3}$ Institute of Parasitology, Slovak Academy of Sciences, Hlinkova 3, 04001 Košice, Slovak Republic, E-mail: reiter@saske.sk; ${ }^{4}$ State veterinary and Food Institute, Botanická ulica 15,84252 Bratislava, Slovak Republic, E-mail: valentova@svuba.sk, beladicova@svuba.sk
\end{abstract}

\section{Summary}

The aim of our study was to determine the prevalence of toxocariasis in Bratislava and smaller towns in western Slovakia. During 2006 - 2011, sand samples collected from 121 sandpits were investigated: 63 sandpits were from Bratislava City and 58 from sandpits in towns outside Bratislava (Malacky, Pezinok Stupava). In Bratislava, $27 \%$ of examined sandpits were contaminated with Toxocara spp. eggs. In smaller towns eggs of Toxocara spp. were found from three sandpits $(6.8 \%)$ of Pezinok and Stupava only. In Malacky, no faeces and no eggs were found in any sandpits. Faecal samples of 1436 dogs and 263 cats were investigated. T. canis eggs were found in the faeces of $16.5 \%$ dogs and T. cati in $18.6 \%$ of examined cats. Toxocariasis of dogs was significantly higher in smaller towns such as the city Bratislava $(\chi 2=10.88$ for $\mathrm{P}$ $\leq 0.001)$. The difference in prevalence of $T$. cati in cats bred in Bratislava and outside Bratislava was not confirmed $(\mathrm{P} \leq 0.05) .382$ pregnant women were examined by ELISA. Anti-Toxocara antibodies were detected in 32 women $(8.4 \%)$. The difference in seroprevalence of women coming from Bratislava (6.6\%) and smaller towns outside Bratislava (11.0\%) was not statistically significant $(\chi 2=1.6 ; \mathrm{P} \leq 0.05)$.

Keywords: Toxocara canis; Toxocara cati; toxocariasis; sandpits; prevalence

\section{Introduction}

Human larval toxocariasis ranks among the most serious zoonotic infections worldwide, being the most commonly diagnosed tissue helminthosis in Slovakia. The causal agents are the larvae of Toxocara canis (dog roundworm) and Toxocara cati (feline roundworm) migrating through the tissues. Humans become infected by ingesting of viable embryonated eggs, shed via the faeces of infected animals in the large quantities into the environment. The human infection occurs most often in children; usually those with geophagia, as well as due to inadequate hygiene, by licking contaminated fingers, toys and other objects (Eberhard, 1998; Kinčeková et al., 1999; Reiterová et al., 2003; Alderete et al., 2003). An important mode of transmission is consumption of raw unwashed food, especially vegetables. The risk of infection is higher in professions involving a close contact with soil, wastewaters, and exposure to dog and cat faeces (Deutz et al., 2005). The infection can be transmitted also by contaminated passive vectors (synantropic flies) as well as by consumption of undercooked meat or viscera from a paratenic host (Pegg, 1971; Morimatsu et al., 2006). The possibility of congenital infection in humans is being discussed (Reiterová et al., 2001). In humans, the Toxocara spp. larvae never mature into adult worms, but the ascarid larvae of Toxoca-ra canis and $T$. cati can penetrate into various organs, whe-re they may survive for many years. Their migration may cause the mechanical damage of the tissues and formation of multiple eosinophilic granulomas sized $1-2 \mathrm{~mm}$. They are localised predominantly in the liver, lungs, in the heart muscle, kidneys, intestinal wall, mesenteric nodes, pancreas and brain (Mirdha \& Khokar, 2002). The clinical signs or symptoms of Toxocara infection include abdominal pain, headaches, anorexia, lymphadenitis, symptoms of atopic disease (Wiśniewska-Ligier et al., 2012). One of the most serious complications is the devastating ocular effect (Pivetti-Pezzi, 2009; Veralo et al., 2012).

The contamination of urban and rural environment by Toxocara eggs and larval toxocariasis in humans and animals are a common problem not only in Slovakia, but worldwide. Toxocara spp. eggs can be commonly found in soil, sand and similar loose substrates, which animals very much like to defecate on. Thus are contaminated faeces spread into the environment, even over great distances (Uhlíková \& Hübner, 1983; Reiterová et al., 2003). Seriously contaminated sites are public parks, where eggs 
are being dispersed into the air during mowing the lawn (Coelho, 2004; Totková et al., 2006). The number of dogs and cats, especially in urban areas, is ever so increasing, so their share on environmental contamination with Toxocara eggs has often been discussed. But stray cats still play an important role in epidemiology of toxocariasis (Talvik et al., 2006).

The aim of our study was to determine the prevalence of toxocariasis in Bratislava and smaller towns in western Slovakia. The project consisted of three partial tasks: 1. Detection of environmental contamination (sandpits, parking areas) by Toxocara spp. eggs in selected districts of Bratislava City: Devínska Nová Ves, Lamač, and Old Town, and in the small towns in western Slovakia (Malacky, Stupava, Pezinok). 2. Identification of Toxocara canis and Toxocara cati in dogs and cats kept in Bratislava and three cities in western Slovakia. 3. Determination of seroprevalence of larval toxocariasis in selected samples of healthy human population in Bratislava and three cities in western Slovakia.

\section{Materials and methods}

\section{Biological material}

During 2006 - 2011, sand samples collected from 121 children sandpits in order to identify the incidence of Toxocara spp. eggs in the environment were investigated. Out of them 63 sandpits were from Bratislava city (Devínska Nová Ves - 33, Lamač - 19, Old Town - 11), and 58 sandpits were located in towns outside Bratislava (Malacky - 23, Pezinok - 21, Stupava - 14). Faeces present in the sandpits were also collected. The whole material included dog faeces; cat faeces were not found.
The prevalence of toxocariasis in dogs and cats was determined in the samples of faeces from 1436 dogs (621 from Bratislava and 815 places outside Bratislava) and 263 cats (114 from Bratislava and 149 from towns outside Bratislava). The study included dogs and cats kept in households that have a close contact with the external environment.

To determine the seroprevalence of toxocariasis in a healthy human population, sera of pregnant women examined within preventive serological screening of toxoplasmosis were used. Altogether 382 sera of Toxoplasma-negative pregnant women aged from 16 to 44 years were examined; out of them 228 samples were from Bratislava and 154 sera were from Malacky, Stupava, and Pezinok. Clinical symptoms of the disease were not observed in any of the females. The samples were collected at the health care centres within the catchment area of the HPL (Ltd) Medical Laboratories in Bratislava.

The sand samples were examined according to the method of Červová (1986). Out of each square meter of sand, a representative sample of approximately $50 \mathrm{~g}$ of sand was examined. It was achieved by mixing sand from 20 samples (approximately $1000 \mathrm{~g}$ of sand) collected at various depths (up to $30 \mathrm{~cm}$ ). The samples were stored in a cool box $\left(4{ }^{\circ} \mathrm{C}\right)$ until the examination and were processed by the concentration method using Tween 40 and $\mathrm{NaNO}_{3}$. After the flotation, the parasite eggs were microscopically examined with a 100, 200, and 400x magnification.

The faeces collected from sandboxes were examined microscopically, after concentration with flotation method with zinc sulphate $\left(\mathrm{ZnSO}_{4}\right)$ (Tolarová et al., 1986). Similarly were examined the samples of cat and dog faeces, sent from veterinary practices and health centres to the

Table 1. The incidence of Toxocara spp. eggs in dog faeces collected from sandpits in Bratislava and in three towns in western Slovakia

\begin{tabular}{|c|c|c|c|c|c|c|c|c|c|}
\hline \multirow{2}{*}{$\begin{array}{l}\text { Bratislava - } \\
\text { district of the } \\
\text { city }\end{array}$} & \multirow{2}{*}{$\begin{array}{c}\text { Sandpits } \\
\text { No. }\end{array}$} & \multicolumn{2}{|c|}{$\begin{array}{c}\text { Animal faeces in } \\
\text { the sandpits }\end{array}$} & \multicolumn{2}{|c|}{$\begin{array}{l}\text { Toxocara spp. } \\
\text { in faeces }\end{array}$} & \multicolumn{2}{|c|}{$\begin{array}{l}\text { Toxocara spp. } \\
\text { in sand }\end{array}$} & \multicolumn{2}{|c|}{$\begin{array}{c}\text { Toxocara spp. } \\
\text { total }\end{array}$} \\
\hline & & No. & $\%$ & No. & $\%$ & No. & $\%$ & No. & $\%$ \\
\hline Old Town & 11 & 2 & 18.2 & 2 & 100 & 0 & 0 & 2 & 18.2 \\
\hline D. N. Ves & 33 & 20 & 60.6 & 7 & 35.0 & 5 & 15.2 & 12 & 36.4 \\
\hline Lamač & 19 & 3 & 15.8 & 2 & 66.7 & 1 & 5.3 & 3 & 15.8 \\
\hline Total & 63 & 25 & 39.7 & 11 & 44,0 & 6 & 9.5 & 17 & 27.0 \\
\hline \multicolumn{10}{|l|}{$\begin{array}{c}\text { Towns in } \\
\text { western Slovakia }\end{array}$} \\
\hline Malacky & 23 & 0 & 0 & 0 & 0 & 0 & 0 & 0 & 0 \\
\hline Pezinok & 21 & 2 & 9.5 & 2 & 100 & 0 & 0 & 2 & 9.5 \\
\hline Stupava & 14 & 1 & 7.1 & 1 & 100 & 1 & 7.1 & 2 & 14.2 \\
\hline Total & 58 & 3 & 5.2 & 3 & 100 & 1 & 1.7 & 4 & 6.8 \\
\hline
\end{tabular}


Table 2. Toxocara spp. eggs in fenced and unfenced sandpits in Bratislava

\begin{tabular}{lccc}
\hline \multicolumn{1}{c}{ Sandbox } & Total & \multicolumn{2}{c}{ Toxocara spp. } \\
& & No. & $(\%)$ \\
\hline Fenced & 38 & 12 & 31.6 \\
Unfenced & 25 & 5 & 20.0 \\
Examined total & 63 & 17 & 27.0
\end{tabular}

Parasitological Laboratory of the State Veterinary and Food Administration in Bratislava on a daily basis.

Enzyme-linked immunosorbent assay for determination of specific antibody production

Sera of pregnant women were examined by ELISA using excretory-secretory antigen for the detection of IgG antibodies against Toxocara canis. Serological examinations were evaluated on the level of specific antibodies, corresponding to the relevant values of absorbance at $492 \mathrm{~nm}$ : low values $0.600-0.900 \mathrm{~nm}$; medium values $0.901-$ $1.200 \mathrm{~nm}$ and high values $1.201 \mathrm{~nm}$ and more (Havasiová et al., 1993).

Statistical analysis

The results were analysed with the $\chi^{2}$ test (Kmety et al., 1983).

\section{Results}

In Bratislava, out of 63 examined sandpits, Toxocara eggs were detected in 17 (27\%) of them. The eggs were present dispersed in the sand and randomly collected faeces; the occurrence of eggs of Toxocara spp. in particular districts correlates with the presence of faeces in the sandboxes. The highest contamination with Toxocara eggs was found in Devínska Nová Ves (36.4\%); the eggs were detected in 5 sandpits $(15.2 \%)$ and 7 samples of the faeces $(35.0 \%)$ present in the sandpits. The significantly highest contamination of sandpits with dog faeces $(60.6 \%)$ was recorded in comparison to their occurrence in the Lamač district $\left(15.8 \% ; \chi^{2}=9.82, \mathrm{P} \leq 0.01\right)$, and equally in the Old Town district $\left(18.2 \%, \chi^{2}=5.94, \mathrm{P} \leq 0.05\right)$. In three towns in Western Slovakia, out of 58 sandpits, eggs of Toxocara spp. were found in the towns of Pezinok and Stupava only; where the eggs of ascarids were present only in three sandpits $(6.8 \%)$ : in two samples of faeces found in a sandpit in Pezinok, in Stupava the eggs were present in a single sandbox in faeces and the sand. In Malacky, no faeces and no eggs were found in any of the investigated sandpit (Tab. 1).

In the districts of Bratislava, out of 63 sandpits, 38 (60.3\%) were fenced, and 25 (39.7\%) unfenced. Toxocara eggs were found in 12 fenced sandpits (31.6\%). Surprisingly, ascarid eggs were found only in 5 unfenced sandpits $(20.0 \%)$, but the difference was statistically insignificant $\left(\chi^{2}=1.03, \mathrm{P} \leq\right.$ 0.05) (Tab. 2).

During 2006 - 2010, faecal samples of 1436 dogs and 263 cats were investigated. T. canis eggs were found in the faeces of $16.5 \%$ of dogs and $T$. cati in $18.6 \%$ of examined

Table 3. Coprological findings of parasites in dog faeces

\begin{tabular}{ccccccc}
\hline \multirow{2}{*}{ Town } & \multicolumn{2}{c}{ Bratislava } & \multicolumn{2}{c}{ Malacky, Pezinok, } & \multicolumn{2}{c}{ Total } \\
& No. & $(\%)$ & No. & $(\%)$ & No. & $(\%)$ \\
\hline Examined total & 621 & 43.2 & 815 & 56.8 & 1436 & 100.0 \\
Positive & 291 & 46.8 & 474 & 50.3 & 613 & 42.7 \\
\hline Toxocara canis & 80 & 12.9 & 157 & 19.2 & 237 & 16.5 \\
Strongyloides spp. & 8 & 1.3 & 18 & 2.2 & 26 & 1.8 \\
Trichuris vulpis & 9 & 1.5 & 14 & 1.7 & 23 & 1.5 \\
Ancylostoma caninum & 18 & 2.9 & 17 & 2.1 & 35 & 2.4 \\
Uncinaria spp. & 1 & 0.2 & 2 & 0.2 & 3 & 0.1 \\
Taenia sp. & 3 & 0.5 & - & - & 3 & 0.1 \\
Diphylidium caninum & 1 & 0.2 & - & - & 1 & 0.07 \\
Mesocestoides & - & - & 1 & 0.1 & 1 & 0,07 \\
Giardia spp. & 99 & 15.9 & 158 & 19.4 & 257 & 17.8 \\
Isospora spp. & 60 & 9.7 & 101 & 12.4 & 161 & 11.2 \\
Demodex spp. & 10 & 4.9 & 6 & 0.7 & 16 & 1.11 \\
Cheyletiella yasguri & 2 & 0.3 & 1 & 0.1 & 3 & 0.01 \\
\hline
\end{tabular}


Table 4. Coprological findings of parasites in cats faeces

\begin{tabular}{ccccccc}
\hline \multirow{2}{*}{ Town } & \multicolumn{2}{c}{ Bratislava } & \multicolumn{2}{c}{ Malacky, } & \multicolumn{2}{c}{ Total } \\
& No. & $(\%)$ & No. & $(\%)$ & No. & $(\%)$ \\
\hline Total of examined & 114 & 54.5 & 149 & 45.5 & 263 & 100 \\
Positive & 46 & 40.4 & 83 & 55.7 & 129 & 49.1 \\
\hline Toxocara cati & 20 & 17.5 & 29 & 19.4 & 49 & 18.6 \\
Strongyloides spp. & 2 & 1.8 & 7 & 4.7 & 9 & 3.4 \\
Toxascaris leonina & - & - & 1 & 0.7 & 1 & 0.4 \\
Taenia spp. & - & - & 1 & 0.7 & 1 & 0.4 \\
Toxoplasma gondii & 1 & 0.9 & 2 & 1.3 & 3 & 1.1 \\
Isospora spp. & 14 & 12.2 & 25 & 16.8 & 39 & 14.8 \\
Giardia spp. & 9 & 7.9 & 17 & 11.4 & 37 & 14.1 \\
\hline
\end{tabular}

cats (Tab. 3, 4). The difference in the prevalence of ascarid worms in dogs and cats was not statistically significant $\left(\chi^{2}\right.$ $=0.67, \mathrm{P} \leq 0.05)$. Substantially higher prevalence of $T$. canis was detected in dogs bred in towns outside Bratislava than was that in dogs in Bratislava $\left(\chi^{2}=10.88, \mathrm{P} \leq 0.001\right)$. The difference in prevalence of $T$. cati in cats bred in Bratislava and outside Bratislava $(\mathrm{P} \leq 0.05)$ was not confirmed. coccidian Isospora felis (14.8\%) and Giardia intestinalis (14.1\%). As for the helminths, Strongyloides spp. was found in nine cats $(3.4 \%)$. Toxascaris leonina and Taenia spp. occurred occasionally in cats originating from towns outside Bratislava (Table 4).

Out of 382 pregnant women, anti-Toxocara antibodies were detected in 32 females (8.4\%). In Bratislava, $15 \mathrm{~s}$ eropositive females were detected $(6.6 \%)$; in the towns

Table 5. Anti-Toxocara IgG antibodies detected in sera of pregnant women

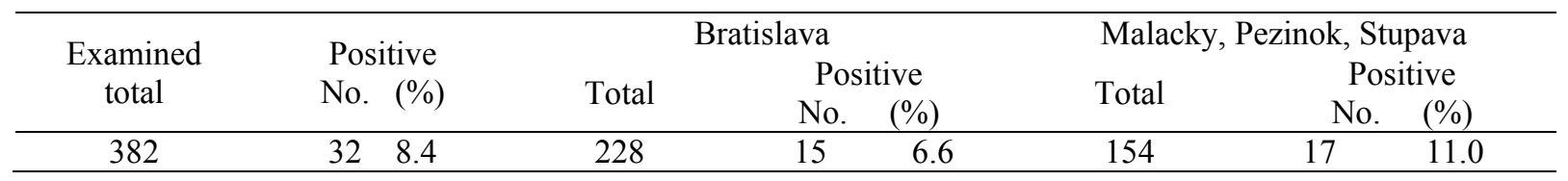

Another 12 parasite species were detected in dogs, eight helminth species and four parasitic protozoans. The most frequent parasite was Giardia spp., which occurred at the same rate $(17.8 \%)$ as Toxocara canis $(16.5 \%)$ and protozoan parasite Isospora spp., present in $11.2 \%$ of the dogs. Significant differences between other parasites in infected dogs in and outside Bratislava were not observed. Other parasites occurred sporadically (Table 3 ).

Besides Toxocara eggs, the faeces of examined cats contained another three species of parasitic worms and cysts of three protozoan species. The most abundant species were outside Bratislava, the number reached 17 females $(11.0 \%)$ (Tab. 5). The difference was not statistically significant $\left(\chi^{2}=1.6, \mathrm{P} \leq 0.05\right)$. In the majority of the cases, low titres of antibodies $(53.1 \%)$ were detected. Threshold and middle titres were represented with equal frequency (27.6\%, respectively. $21.9 \%$ ) (Table 6).

\section{Discussion}

In humans, the larvae of cat and dog roundworms cause severe disease occurring worldwide. An increasing number

Table 6. The frequency of IgG antibody titers against Toxocara spp. in pregnant women $(\mathrm{n}=32)$

\begin{tabular}{lcccccc}
\hline \multirow{2}{*}{ Titre } & \multicolumn{2}{c}{ Bratislava } & \multicolumn{2}{c}{ Malacky, Pezinok, } & \multicolumn{2}{c}{ Total } \\
& No. & $\%$ & No. & $\%$ & No. & $\%$ \\
\hline Cut off titre $(1: 100)$ & 4 & 26.7 & 4 & 23.5 & 8 & 25.0 \\
Low titre $(1: 200)$ & 10 & 66.7 & 7 & 41.2 & 17 & 53.1 \\
Middle titre $(1: 400-800)$ & 1 & 6.7 & 6 & 35.3 & 7 & 21.9 \\
\hline
\end{tabular}


of cats and dogs in urban and rural agglomerations, the majority of them not being in the care of a veterinarian, as well as, close contact of man to the contaminated environment pose the risk of infection. In Slovakia, larval toxocariasis is the most commonly diagnosed tissue helminthosis. In epidemiology of larval toxocariasis, the contamination of the environment with Toxocara eggs is a key factor. There are numerous studies, documenting the different status in the occurrence of roundworms in different cities. In Košice (Slovak Republic), Juriš et al. (1991) reported eggs of Toxocara spp. in $18.8 \%$ of sandpits, in faeces and the soil of public areas. In Prague (Czech Republic), Dubná et al. (2007) found $20.4 \%$ of sandpits contaminated with Toxocara eggs. In Krakow (Poland), Mizgajska (2000) detected Toxocara eggs in $30 \%$ of the soil samples from public places. High contaminations of sandpits (84\%) were detected by Duwel (1984) in Frankfurt am Main, Germany. In Greece, Himonas et al. (1992) found $97.5 \%$ of children playgrounds contaminated with roundworm eggs. Abe and Yakusava (1997) in Osaka (Japan) found eggs of Toxocara spp. in $75 \%$ of children sandpits. Our results provided an interesting overall picture. While, in selected urban areas of Bratislava, we recorded roundworm eggs in up to $27 \%$ of children playgrounds, in the smaller towns outside of Bratislava Toxocara eggs were found only in $6.8 \%$ of sandpits. In Bratislava, we found an alarmingly high percentage of sandpits contaminated by dog faeces $(39.7 \%)$. Faeces occurred both on the surface of the sand and in deeper layers. Toxocara spp. Eggs were present in $44 \%$ of faeces samples, which is more than twice as many samples as found in other parts of Bratislava by Totková et al. (2006) (18.7\%). Similarly, Komžíková (1997) in Prievidza found Toxocara spp. eggs in $19 \%$ of faecal samples collected from public spaces.

The highest contamination of sandpits with roundworm eggs and faeces was observed in the outskirts of Bratislava - in Devínska Nová Ves. In the cities outside Bratislava, dog faeces contaminated with eggs of Toxocara spp. were found only in two sandboxes in Pezinok and one in Stupava. In Malacky, faeces or eggs were not found in any of the sandpits. Supposedly, it might be due to careful treatment of sand only in the cities and responsible approach of pet owners that regularly collect their pet faeces within those areas.

Although the selected sandpits and public areas contained only dog faeces, the high prevalence of Toxocara spp. in the district of D. N. Ves may be due to stray cats. It will be necessary to confirm such assumption in order to take the preventive measures. Uga (1996) found that cats tend to disperse their faeces around the sandpits, which contributes most to the subsequent contamination.

This phenomenon could explain the absence of cat faeces in our samples, which were not found in any of the sandpits. Moreover, such assumption could be confirmed by the presence of ascarids eggs in fenced sandpits that do not prevent a cat from entering the playground. In fenced sandboxes, we detected eggs of Toxocara spp. relatively more frequently $(31.6 \%)$ than in unfenced $(20 \%)$. We confirmed the findings of Abe and Yasukawa (1997), and Uga and Kataoka (1995) that a fence will not prevent the sandpits from further contamination. T. canis and $T$. cati eggs are morphologically hardly distinguishable (Dubna et al., 2007), so we were unable to determine the proportion of cats and dogs on the contamination of sandpits with ascarids. For the species determination of the eggs, methods of molecular differentiation of PCR (polymerase chain reaction) and LAMP (loop-mediated isothermal amplification) appeared appropriate (Borecká \& Gawor, 2008, Mačuhová et al., 2010).

The low contamination of sandpits with roundworm eggs in the towns outside Bratislava is in contrast to the relatively high prevalence of toxocariasis in dogs and cats (dogs $-19.2 \%$, cats $-19.4 \%$ ) bred in these towns. Infectivity of those cats is comparable to the infectivity of cats kept in Bratislava (17.5\%), while, in dogs, it was significantly higher in the dogs from the cities outside Bratislava that in Bratislava dogs $(\mathrm{P}<0.001)$. We assume that it is associated with free movement, the possibility to catch and eat small rodents, which may influence the infection of dogs and cats in rural areas.

In Hanover, on the contrary, Mundhenke \& Daugschies (1999), found a higher prevalence of Toxocara cati in cats living in rural areas $(7.9 \%)$ than was that in urban areas (4.7\%). The high detected amount of dogs $(16.5 \%)$ with canine ascarids corresponds to literature data published in Slovakia: Antalíková (1995) found T. canis in $10.5 \%$ dogs, Antolová et al. (2004) reported T. canis infection in $16.6 \%$ of dogs. In 32 villages of South Moravia, Borkovcová (2003) found roundworms in $9.5 \%$ of adult dogs and $22.2 \%$ of puppies. In Poland, Luty (2001) indicated up to $32.0 \%$ occurrence of T.canis in dogs. Up to $97.3 \%$ prevalence of Toxocara canis in dogs was recorded in Bulgaria (Šoilev et al., 1984). Due to the fact that even as low as 7 percent prevalence of Toxocara infection in dogs may pose a health risk to humans (Preiss, 1982), our data can be considered relevant in terms of epidemiology of larval toxocariasis. In cats, we found a higher prevalence of toxocariasis than in dogs $(18.6 \%$, respectively $16.5 \%$ ), but those values were not statistically significant. However, it is significantly lower prevalence than indicated by Antalíková (1995), who found roundworms in $44.5 \%$ of cats during 1973 - 1994. Similar values in cats $(39.0 \%)$ in Poland were reported by Luty (2001). In contrast, our data correspond to the findings of Borkovcová (2002) in the Czech Republic, who found ascarids in $14.2 \%$ of cats. High prevalence of roundworms in cats $(52.8 \%)$ was documented in Iran (Sadjjadi et al., 2001).

In addition to eggs of Toxocara spp. detected in the fecal samples, several other parasite species were found in dogs. Giardia spp. was as frequent $(17.8 \%)$ as T. canis $(16.5 \%)$. The occurrence of Isospora spp. was significantly lower in dogs than was that in cats $\left(11.2 \%\right.$, respectively $14.8 \%$, $\chi^{2}$ $=9: 48$ for $\mathrm{P}<0.01)$. Besides the eggs $T$. cati, six additional species of parasites were detected in cats from Bratislava and smaller towns close to Bratislava; dominated by parasitic protozoans Isospora spp. and Giardia spp. Simi- 
larly, a high prevalence of both significant zoonotic parasites in dogs and cats was detected in the Netherlands (Overgaauw, 2009) and in dogs in Belgium and Japan (Claerebout et al., 2009, Naoyuki et al., 2009).

Despite the high prevalence of toxocariasis in dogs and cats, as well as high environmental contamination with eggs of Toxocara spp. in Bratislava, the seroprevalence of toxocariasis in healthy pregnant women from Bratislava showed relatively low values $(6.6 \%)$. We also found a similar occurrence of antibodies in pregnant women in Malacky Pezinok and Stupava (11.0\%).

Lower seroprevalence of toxocariasis is documented by Pavlínová et al. (2011) in pregnant women with a history of habitual abortion $(5.5 \%)$. Low prevalence of toxocariasis in pregnant women $(3.1 \%$ ) (samples of the healthy population) was recorded in the Danish population by Stensvold et al. (2009).

The occurrence of toxocariasis varies by region, population group, and depends on hygiene practices, and other factors. (Reiterová et al., 2003). In Slovakia, Havasiová et al. (1993) detected antibodies in $13.7 \%$ of blood donors. Similarly Jalili et al. (1997) proved the seropositivity in $15.2 \%$ of blood donors from West Slovakia. In contrast, Savigny et al. (1979) in England documented seropositivity only in $2.6 \%$ of blood donors. In Sweden, Ljungström and van Knapen (1989) found antibodies in $7.0 \%$ of the healthy population; in Turkey, Kaplan et al. (2004) also in $7.1 \%$ of healthy persons. The highest seroprevalence $86 \%$ is recorded in Saint Lucia, in the Caribbean area (Safar et al., 1990). Alderete et al. (2003) in Brazil found antibodies against Toxocara spp. in $38.8 \%$ of healthy children and observed a statistically significant correlation between occurrence of antibodies and low hygiene practices. Fan et al. (2004) reported up to $75.6 \%$ of seropositive healthy children living in Taiwan, in an environment contaminated by eggs of Toxocara spp. Kaplan et al. (2004) detected a substantially higher seroprevalence in groups of mentally disabled persons $(18.8 \%)$ than was that in a sample of healthy individuals (7.1\%).

Many authors indicate higher seroprevalence in the rural areas in comparison to towns. Uhlíková and Hübner (1983) in the Czech Republic observed a substantially higher seroprevalence $(33.7 \%)$ in rural population than in the towns $(13.2 \%)$. Significantly higher seropositivity in the urban population $(9,2 \%)$ in comparison to people living in rural areas (15.5\%) is documented by Ondriska (1997).

The results of our study suggest the need for paying permanent attention to larval toxocariasis. A high level of Toxocara infection in dogs and cats in above-mentioned cities, and seroprevalence in healthy adult humans refer to inadequate prevention practices.

\section{References}

ABe, N., Yasukawa, A. (1997): Prevalence of Toxocara spp. eggs in sandpits of parks in Osaka city, Japan, with notes on the prevention of egg contamination by fence construction. J. Vet. Med. Sci., 59: $79-80$
Alderete, J. M. S., Jacob, C. M. A., Pastorino, A. C., Elefant, G. R., Castro, A. P. M., Fomin, A. B. F., ChIEFFI, P. P. (2003): Prevalence of Toxocara infection in school children from the Butanta region, Sao Paulo, Brazil. Mem Inst Oswaldo Cruz., 98: 593 - 597

AnTAlíkOVÁ, J. (1995): The occurrence of certain helminths of dogs and cats in Bratislava and Western Region of Slovakia for the period from 1973 to 1994. Thesis, Slovakia, Bratislava: Faculty of natural Sciences, Comenius University in Bratislava

Antolova, D., Reiterova, K., Miterpakova, M., Stanko, M., Dubinsky, P. (2004): Circulation of Toxocara spp. in suburban and rural ecosystems in the Slovak Republic. Vet. Parasitol., 126: 317 - 324. DOI: 10.1016/j.vetpar.2004.08.005

BORECKA A., GAWOR J. (2008): Modification of gDNA extraction from soil for PCR designed for the routine examination of soil samples contaminated with Toxocara spp. eggs. J. Helminthol., 82: 119 - 122. DOI: 10.1017/S0022149X07877522

BorkovCOvÁ, M. (2003): Prevalence of intestinal parasites of dogs in rural areas of South Moravia (Czech Republic). Helminthologia, 40: 141 - 146

Claerebout, E., Casaert, S., Dalemans, A. C., De Wilde, N., Lavecke, B., Vercruysse, J., Geurden, T. (2009): Giardia and other intestinal parasites in different dog populations in Nothern Belgium. Vet. Parasitol., 161: $41-46$

Coelho, L. M. (2004): Human toxocariasis: a seroepidemiological survey in schoolchildren of Sorocaba, Brazil. Mem. I. Oswaldo Cruz., 99: 553 - 557

ČErVovÁ, H. (1986): The method of laboratory testing of soil and sand. Acta. Hyg. Epid. Microbiol., 1: 12 - 15 [In Czech]

Deutz, A., Fuchs, K., Auer, H., Kerbl, U., Aspöck, H., KÖFER, J. (2005): Toxocara-infestations in Austria: a study on the risk of infection of farmers, slaughterhouse staff, hunters and veterinarians. Parasitol. Res., 97: 390 - 394

Dubná, S., Langrová, I., Vadlejch, J., Pekar, S., NÁPRAVNIK, J., FECHTNER, J. (2007): Contamination of soil with Toxocara eggs in urban (Prague) and rural areas in the Czech. Republic. Vet. Parasitol., 144: $81-86$

Duwel, D. (1984): The Prevalence of Toxocara eggs in the sand in childrens playgrounds in Frankfurt. Ann. Trop. Med. Parasitol., 78: $633-636$

Eberhard, M. L., AlfanO, E. (1998): Adult Toxocara cati infections in US children: Report of four cases. Am. J. Trop. Med. Hyg., 59: $404-406$

FAn, C. K., HunG, C. C., Du, W. Y., LiaO, C W., Su, K. E. (2004): Seroepidemiology of Toxocara canis infection among mountain aboriginal schoolchildren living in contaminated districts in eastern Taiwan. Trop. Med. Int. Health., 9: $1312-1318$

HAVASIOVÁ, K., DUBINSKÝ, P., ŠTEFANČíKOVÁ, A. (1993): A seroepidemiological study of human Toxocara infection in the Slovak Republic. J. Helminthol., 67: $291-296$

Himonas, C., Antoniadou-Sotiriadou, K., Frydas, S. (1992): Research survey on the prevalence of Toxocara 
ova in the soil of public parks in Thessaloniki. HellinikiTatriki, 58: $333-339$

Jalili, N. A., Holková, R., Valent, M., Degma, P., ČERVEŇ, D. (1997): Detection of Toxocara IgG antibodies in human sera by ELISA for the years 1994 - 1996. In: Abstracts of Current Problems of Human Parasitology. Slovak Society for Parasitology, Parasitological Institute Faculty of Medicine in Bratislava, June 13, 1997. Faculty of Medicine, Bratislava, SR, 1997, pp. 20 - 21. [In Slovak] Juriš, P., PlachÝ, P., DubinskÝ, P. (1991): Hygienic problems of dog breeding in urban habitats, with a focus on Toxocara spp. In Ecology and veterinary medicine, pp. 24

Kaplan, M., Kalkan, A., Hosoglu, S., KuK, S., Ozden, M., Demirdag, K., Ozdarendeli, A. (2004): The frequency of Toxocara infection in mental retarded children. Mem. I. Oswaldo Cruz., 99: $121-125$

KinČeKovÁ, J., ReiterovÁ, K., DubinskÝ, P. (1999): Larval toxocariasis and its clinical manifestation in childhood in the Slovak Republic. J. Helminthol., 73: 323 - 328 Kmety, E., Bakoss, P., BazovskÁ, S., Guryčová, D., Straka, Š., BADAlík, L., Junas, J., PríkAZSKÝ, V., HLAVÁČKOVÁ, L. (1983): Epidemiology. Textbook Faculty of Medicine. Osveta, Bratislava, Slovakia, 185 pp. [In Slovak]

KomžíkovÁ, A. (1997): Intestinal parasites of canine and feline carnivores in region of Nitra. Thesis, Slovakia, Bratislava: Faculty of natural Sciences, Comenius University in Bratislava, Slovakia, 56 pp. [In Slovak]

LJUNGSTRÖM, I., VAN KNAPEN, F. (1989): An epidemiological and serological study of Toxocara infection in Sweden. Scand. J. Infect. Dis., 21: 87 - 93

LUTY, T. (2001): Prevalence of species of Toxocara in dogs, cats and red foxes from the Poznan region, Poland. $J$. Helminth., 75: $153-156$

Macuhova, K., Kumagai, T., AkaO, N., OHtA, N. (2010): Loop-mediated isothermal amplification assay for detection and discrimination of Toxocara canis and Toxocara cati eggs directly from sand samples. J. Parasitol., 96: $1224-1227$

MatsuO, J., NAKAshio, S. (2005): Prevalence of fecal contamination in sandpits in public parks in Sapporo City, Japan. Vet. Parasitol., 128: 115 - 119

MirdHA, B. R., KHOKAR, S. K. (2002): Ocular toxocariasis in a north Indian population. J. Trop. Pediatr., 48: $328-$ 330

MizgajSKA-WikTor, H., UGA, S. (2006): Exposure and Environmental Contamination. In: Holland, C. V., and Smith, H. V. (Eds) Toxocara: the enigmatic parasite. Oxfordshire, CABI Publishing, pp. $211-227$

Morimatsu, Y., AKaO, N., AKIYOShi, H., KawazU, T., OKABE, Y., AIZAWA, H. (2006): Case reports: A familial case of visceral larva migrans after ingestion of raw chicken livers: Appearance of specific antibody in bronchoalveolar lavage fluid of the patients. Am. J. Trop. Med. Hyg., 75: $303-306$

Mundhenke, H., Daugschies, A. (1999): Studies on the prevalence of endoparasites in cats in Hannover and sur- roundings. Wien. Tierarztl. Monat., 86: $43-48$

NaOYUKI, I., KazuTAKa, K., Yasutomo, H., Fumio, H., SEIICHI, H. (2009): Prevalence of Giardia intestinalis and other zoonotic intestinal parasites in private household dogs of the hachinone area in aomori prefecture, japan in 1997, 2002 and 2007. J. Vet. Sci., 10: $305-308$

ONDRISKA, F. (1997): Seroepidemiological survey of larval toxocariasis in some regions of Slovakia. In: Abstracts of Current Problems of Human Parasitology. Slovak Society for Parasitology, Parasitological Institute Faculty of Medicine in Bratislava, June 13, 1997. Faculty of Medicine, Bratislava, SR, 1997, pp. 32. [In Slovak]

Overgaauv, P. A. M., Van ZutPhten, L., Hoeck, D., Yaya, F. O., Roelfsema, J., Pinelli, E., VAN KnAPen, F., KORTEBEEK, L. M. (2009): Zoonotic parasites in fecal samples and fur from dogs and cats in the Netherlands. Vet. Parasitol., 163:115-22. DOI: 10.1016/j.vetpar.

2009.03.044

PAVlinovÁ, J., KinČEKovÁ, J., Ostró, A., SAKSUn, L., VAsilkovÁ, Z., KÖNIGOVÁ, A. (2011): Parasitic infection and pregnancy complications. Helminthologia, 48: 8 - 12 . DOI: $10.2478 / \mathrm{s} 11687-011-0002-x$

PEGG, E. L. (1971): Infection of dogs with Toxocara canis carried by flies. Parasitology, 62: $409-414$

Pivetti-Pezzi, P. (2009): Ocular toxocariasis. Int. J. Med. Sci., 6: 129 - 130. DOI: 10.7150/ijms.6.129

PREISS, U. (1982): Die Toxocariasis im Kindesalter. Larva migrans visceralis- Syndrom. Monatschr. Kinderheit., 130:99 - 104

REITEROVÁ, K., KINČEKOVÁ., TOMAŠOVIČOVÁ, O., DUBINSKÝ, P. (2001): Manifestation of maternal immunity and offspring by larval toxocariasis. In: HoLKOVÁ, ONDRISKA, F., KLOBUŠICKÝ, M. (Eds) Current problems of human parasitology and clinical day of problems of diagnosis and therapy of toxoplasmosis. Slovak Society for Parasitology, Parasitological Institute Faculty of Medicine Comenius University, November 11, 2001. Bratislava, SR: Comenius University, Bratislava, SR, 2003, pp. 9 - 12. [In Slovak]

REITEROVÁ, K., KinČEKOVÁ, J., HALÁSOVÁ, D., MiterPAKOVÁ, M. (2003): Epidemiology and epizootology of toxocariasis. In Holková, R., TotKová, A., KLOBUŠICKÝ, M. (Eds) X. Actual problems of Human Parasitology. Slovak Society for Parasitology, Parasitological Institute Faculty of Medicine Comenius University, December 2, 2003. Bratislava, SR: Comenius University, Bratislava, SR,2003, pp 14 - 17 [In Slovak]

SAdJjadi, S. M., Oryan, A., Jalai, A. R., Mehrabani, D. (2001): Prevalence and intensity of infestation with Toxocara cati in stray cats in Shiraz, Iran. Vet. Arhiv., 71: 149 157

Safar, E. H., Azab, M. E., Khalil, H. M., Bebars, M. A., ElHady, H., KhatTAB, H. M.(1990): Immunodiagnostics of Toxocara canis in suspected ocular and visceral manifestations. Folia Parasit., 37: 249 - 254

de Savigny, D. H., Voller, A., Woodruff, A. W. (1979): Toxocariasis: serological diagnosis by enzyme immunoassay. J. Clin. Path., 32: $284-288$ 
Stensvold, Ch, R., Skov, J., Møller, L. N., Jensen, P. M., Kapel, CH. M. O., Petersen, E., Nielsen, H. V. (2009). Seroprevalence of human toxocariasis in Denmark. Clin. Vaccine Immunol., 16(9): 1372 - 1373

Šoilev, CH., Šeleva, R., Todorov, T., Vutova, K.(1984): Zur Verbreitung von Toxocara canis bei Welpen in der Bulgarien. Angew.Parasitol., 25: 93 - 96

TAlviK, H., MoKs, E., MÄGI, E., JÄRVIS, T., Miller, I. (2006): Distribution of Toxocara infection in the environment and in definitive and paratenic hosts in Estonia. Acta Vet. Hung., 54: 399 - 406

TOLAROVÁ, V., ET AL. (1989): Recomended methods of laboratory diagnosis of tropical parasites. Acta Hyg. Microbiol., Appendix 12., pp. 13

TotkovÁ, A., KlobuŠickÝ, M., HolkovÁ, R., FriedOVÁ, L. (2006): Current prevalence of toxocariasis and other intestinal parasitoses among dogs in Bratislava. Epidemiol. Mikrobiol. Imunol., 55: 17 - 22 [In Slovak]
UGA, S. (1993): Prevalence of Toxocara eggs and number of fecal deposits from dogs and cats in sandpits of public parks in Japan. J. Helminthol., 67: $78-82$

UgA, S., KATAOKA, N. (1995): Measures to control Toxocara egg contamination in sandpits of public parks. Am. J. Trop. Med. Hyg., 52: $21-24$

UHLÍkOVÁ M., HÜBNER, J. (1983): Larval toxocariasis. Avicenum, Praha, CR., 170 pp.

Verallo, O., Fragiotta, S., Verboschi, F., Vingolo, E. M. (2012): Diagnostic Aspects and Retinal Imaging in Ocular Toxocariasis: A Case Report from Italy. Case Reports in Medicine 2012, Article ID 984512, pp. 3, http://www.hindawi.com/journals/crim/2012/984512/.

DOI:10.1155/2012/984512

WIŚNIEWSKA-LIGIER, M., WOŹNIAKOWSKA-GESICKA, T., SOBOLEWSKA-DryJAŃSKA, J., MARKIEWICZ-JÓźWIAK, A., WIECZOREK, M. (2012): Analysis of the course and treatment of toxocariasis in children a long-term observation. Parasitol. Res., 110: 2363 - 2371

ACCEPTED SEPTEMBER 25, 2013 